\title{
PENGEMBANGAN OBJEK WISATA HUTAN MANGROVE BERBASIS EKOWISATA
}

\author{
Ach. Bagus Adhiluhung Mardhotillah*, Ahmad Munawir Uar, Badilla Asran, Ziqli \\ Seban, M Hilsa Gani, Fisabillah Asran, M Sahril Ernas \\ Fakultas Peternakan, Universitas Islam Malang \\ *korespondensi email: achbagusam@unisma.ac.id
}

\begin{abstract}
ABSTRAK
Salah satu desa yang berpotensi untuk wisata Hutan Mangrove di Kecamatan Teluk Ambon Baguala, Kota Ambon adalah Desa Waihru. Desa ini terletak pada wilayah dataran tinggi dengan luas daerah sebesar $2.250 \mathrm{Ha}$, dan panjangnya sekitar 1,5 km. Desa Waiheru memiliki kawasan Hutan Mangrove yang terletak di Pantai Teluk Ambon Desa Waiheru dan berpotensi untuk dijadikan kawasan wisata. melihat potensi yang ada dari hutan mangrove tersebut kami sebagai mahasiswa KSM PPM TEMATIK yang mengabdi di Desa Waiheru, Kecamatan Teluk Ambon Baguala, Kota Ambon turut serta membantu dalam pengembangan objek wisata tersebut. bersama dengan pemuda-pemudi Karang Taruna dan warga Desa Waiher. Berbagai kegiatan dilakukan untuk pengembangan wisata hutan Mangrove di Desa Waiheru antara lain: penanaman pohon Bakau di kawasan Pantai wisata hutan mangrove, pembersihan sampah, pembuatan plang informasi, pembuatan spot selfie untuk mengundang daya tarik wisatawan, dan Kegiatan ini mendapat respon positif dari baik dari warga sekitar.
\end{abstract}

Kata Kunci: ekowisata; hutan mangrove; masyarakat; objek wisata

\section{PENDAHULUAN}

Pariwisata merupakan salah satu dari 5 (lima) sektor pembangunan 2017, yaitu pangan, energi, maritim, pariwisata, kawasan industri dan Kawasan Ekonomi Khusus (KEK), begitu yang tercantum dalam Rencana Kerja Pemerintah (RKP) 2017. Dalam KEK sendiri juga terdapat KEK Pariwisata, pariwisata sebagai sektor yang strategis dan menjadi media integrasi program dan kegiatan antar sktor pembangunan, sehingga pariwisata sangat masuk akal ditetapkan menjadi Leanding pembangunan.

Menurut Undang-Undang Republik Indonesia Nomor 10 Tahun 2009 tentang kepeariwisataan, pariwisata adalah berbagai macam kegiatan dan didukung berbagai fasilitas serta layanan yang disediakan oleh masyarakat, pengusaha, pemerinrah dan pemerintah pusat. Menurut Spillen (1994) dalam suwendan Nugrah (2017), kegiatan pariwisata dapat menjadi besar disebabkan tiga hal. Pertama, penampilan eksotis dari pariwisata, kedua, adanya keinginan dan kebutuhan orang moderen yang disebut hiburan waktu senggang dan ketiga, memenuhi kepentingan politis yang berkuasa dari negara yang dijadikan daerah tujuan pariwisata.

pengembangan pariwisata berkelanjutan yang berbasis pada alam, budaya, heritage, sosial dan ekonomi sarat dengan kompleksitas yang melibatkan wisatawan maupun masyarakat lokal yang bertindak sebagai tuan rumah. konsekuensinya pelestarian dan perlindungan terhadap lingkungan menjadi tanggungjawab kita semua khususnya pihakpihak yang terlibat dalam perencanaan dan pengembangan pariwisata industri, 
pertumbuhan pariwisata sebagai suatu industri harus mempertimbangkan adanya jaminan sumber daya pariwisata tetap terpelihara dan masih dinikmati generasi penerus dimasa yang akan dating (Rumijati et al., 2021).

Untuk mencapai ekowisata, perlu dikembangkannya prinsip-prinsip ekowisata agar tercapai berkelanjutan. Melalui prinsip berbasis ekowisata dapat dijembatani hubungan yang baik antara pengelolah dengan masyrakat. Selain itu melalui pengembangan berbasis ekowisata, tidak hanya sebagai pelestarian lingkungan tetapi juga sebagai perjalanan wisata dan juga wadah edukasi yang baik serta masyarakat lokal juga turut berkontribusi didalam kegiatan wisata berbasis ekowisata.

Desa Waiheru merupakan salah satu desa di kecamatan Kecamatan Teluk Ambon Baguala, Kota Ambon. yang meliki potensi mangrove pada garis pantainya. Desa ini terletak pada wilayah dataran tinggi dengan luas daerah sebesar $2.250 \mathrm{Ha}$, dan panjangnya sekitar 1,5 km. Desa Waiheru memiliki kawasan Hutan Mangrove yang terletak di Pantai Teluk Ambon Desa Waiheru dan berpotensi untuk dijadikan kawasan wisata. melihat potensi yang ada dari hutan mangrove tersebut kami sebagai mahasiswa KSM PPM TEMATIK yang mengabdi di Desa Waiheru, Kecamatan Teluk Ambon Baguala, Kota Ambon turut serta membantu dalam pengembangan objek wisata tersebut. bersama dengan pemuda-pemudi Karang Taruna dan warga Desa Waiher. Berbagai kegiatan dilakukan untuk pengembangan wisata hutan Mangrove di Desa Waiheru antara lain: penanaman pohon Bakau di kawasan Pantai wisata hutan mangrove, pembersihan sampah, pembuatan plang informasi, pembuatan spot selfie untuk mengundang daya tarik wisatawan, dan Kegiatan ini mendapat respon positif dari baik dari warga sekitar.

\section{METODE}

Adapun metode tahapan yang dilakukan untuk pelaksanaan kegiatan ini adalah:

\section{Survei Lokasi}

Tahapan awal dalam penyelenggaraan kegiatan ini adalah survei lokasi untuk mengetahui kesesuaian tema yang dipilih. Hal ini juga dilakukan untuk melihat apakah ada potensi lainnya yang dapat dikembangkan atau ditambahkan dalam pelaksanaannya nanti.

\section{Pembekalan dan Pembentukan Kelompok}

Tahapan selanjutnya adalah mempersiapkan mahasiswa yang akan terlibat dalam kegiatan KSM Tematik. Mahasiswa yang terlibat berasal dari berbagai disiplin ilmu baik Teknik Sipil, Ilmu Administrasi Publik, Ekonomi dan Bisnis, Hukum. Keterlibatan mahasiswa dalam KSM ini diharapkan memiliki kapasitas yang sesuai dengan tema kegiatan. Selanjutnya mahasiswa akan diberikan materi pembekalan kegiatan KSM Tematik untuk memperkuat pengetahuan atas permasalahan dan metode yang akan digunakan sesuai dengan tema KSM Tematik. Materi pembekalan yang akan diberikan kepada mahasiswa yang terlibat dalam kegiatan adalah konsep dasar perencanaan dan pengembangan wisata Mangrove yang berbasis ekowisata dan teknik penyusunan program, evaluasi program, dan penyusunan laporan. Selain itu, mahasiswa dibagi menjadi tiga kelompok, dengan tujuan seluruh rangkaian kegiatan dapat terlaksana sesuai dengan yang diinginkan. Masing-masing kelompok memiliki tugas sesuai dengan rencana kegiatan yang ada. Setiap kelompok mempunyai ketua, sekretaris dan bendahara yang bertanggung jawab untuk kelancaran pelaksanaan kegiatan.

\section{Pelaksanaan Kegiatan}

Tahap awal pelaksanaan diawali dengan melibatkan masyarakat sebagai pelaku utama. Partisipasi masyarakat dapat dibentuk dengan dilakukannya sosialisasi untuk menyamakan visi pelaksanaan KSM Tematik di Desa Waiheru. Kecamatan Teluk Ambon 
Baguala, Kota Ambon. Pemberdayaan masyarakat dalam pengembangan wisata Mangrove berbasis ekowisata diharapkan menjadi solusi dalam permasalahan masyarakat dan merupakan kegiatan yang berkelanjutan. Permasalahan lingkungan membutuhkan penyelesaian secara komprehensif dan berkelanjutan. Seperti yang diketahui, pengembangan wisata Mangrove berbasis ekowisata harus hendaknya menggunakan teknologi yang ramah lingkungan. Tidak menutup kemungkinan adanya penerapan teknologi tepat guna sebagai pendukung dalam mewujudkan pengembangan wisata Mangrove dengan tujuan kemandirian dan kesejahteraan masyarakat secara berkelanjutan.

\section{HASIL DAN PEMBAHASAN}

Kegiatan yang dilakukan dalam pengembangan objek wisata hutan mangrove berbasis ekowisata diantaranya:

\section{Gerakan Penanaman Pohon}

Kegiatan ini dilakukan di sekitar Pantai Wisata Hutan Mangrove, dengan tujuan untuk melakukan penghijauan di area pantai dan wisata hutan mangrove tersebut. Pohon yang ditanam adalah jenis pohon Bakau dan Cemara Laut. Gerakan penanaman pohon ini diikuti oleh mahasiswa KSM, Pemuda-Pemudi Karang Taruna dan warga setempat.

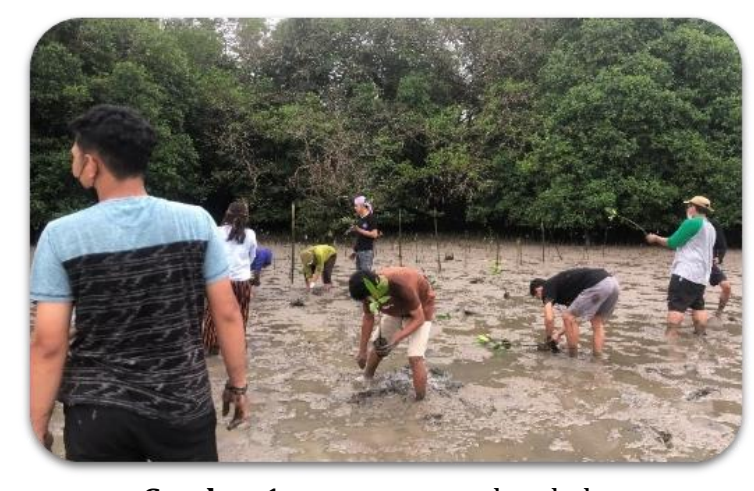

Gambar 1. penanaman pohon bakau

Sebelum bibit tersebut ditanam, lubang tanam diberi pupuk kompos terlebih dahulu dan dibiarkan selama satu malam. Pemberian pupuk kompos ini bertujuan untuk membuat tanah menjadi subur. Sebanyak 200 Pohon Cemara Laut ditanam di sepanjang akses masuk pantai wisata hutan mangrove yang dilakukan selama 2 hari.

\section{Pembersihan Sampah di Area Lingkungan Wisata Mangrove}

Kegiatan pengabdian kepada masyarakat yang telah dilaksanakan tentang sosialisasi dan gerakan bersih pantai sebagai upaya mengurangi sampah di area lingkungan wisata hutan mangrove. Pemebersihan sampah yang berserakan di area lingkungan wisata hutan mangrove ini diupayakan untuk terus melestarikan fungsi lingkungan hidup serta mencegah terjadinya pencemaran atau kerusakan linkungan hidup salah satunya pohon bakau yang sudah di tanam. 


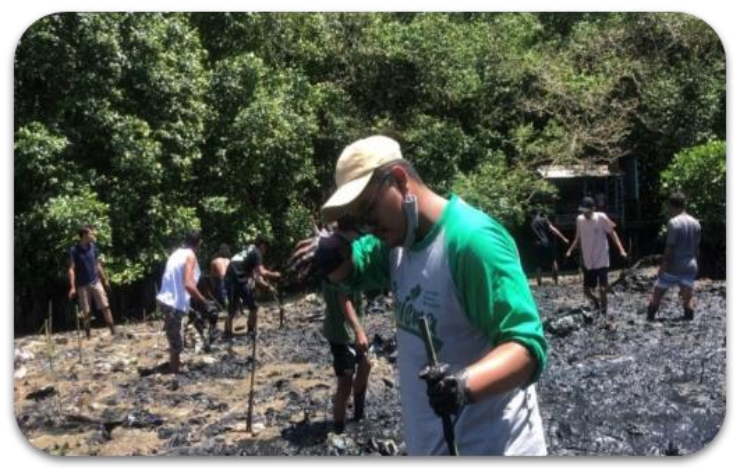

Gambar 2. Pembersihan sampah

Pemebersihan sampah yang berserakan di area lingkungan wisata hutan mangrove ini diupayakan untuk terus melestarikan fungsi lingkungan hidup serta mencegah terjadinya pencemaran atau kerusakan linkungan hidup salah satunya pohon bakau yang sudah di tanam.

\section{Pembuatan Plang Nama Flora dan Fauna}

Salah satu upaya untuk merevitalisasi Pantai Tanjung Raya yang berbasis pendidikan adalah dengan mengidentifikasi, kemudian memperoleh data mengenai nama lokal dan nama ilmiah untuk jenis flora dan fauna disekitar pantai tersebut. Datadata ini dapat bermanfaat bagi masyarakat yang berwisata ke wisata hutan mangrove Desa Waiheru dengan harapan pantai tersebut dapat dikategorikan pantai berbasis pendidikan.

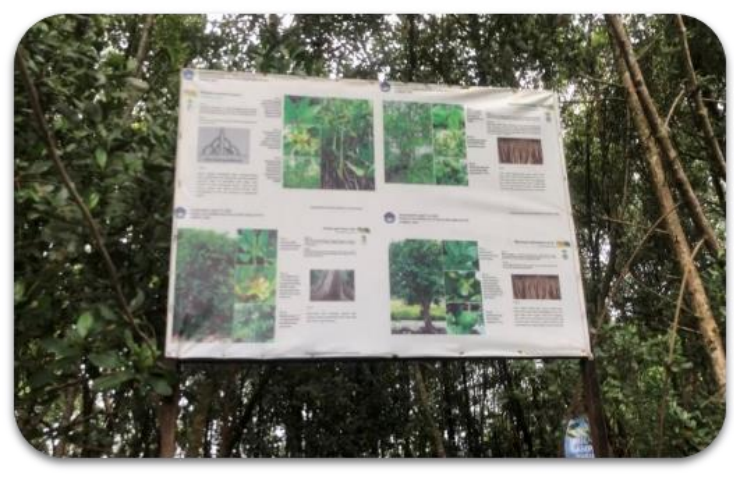

Gambar 3. Plang nama flora dan fauna

Berdasarkan hasil pengamatan yang dilakukan oleh mahasiswa telah teridentifikasi flora dan fauna yang ada di wisata hutan mangrove ini yaitu: Bakau Kurap (Rhizopoda Mucronata), Bakau Kecil (Rizopora Styloca), Bakau Minyak (Rizopora Apiculata), Cemara Laut (Casuarina Equisetifolia), Kepiting Bakau (Scylla spp), Rajungan dan Burung Punai (Green Pigeon).

\section{KESIMPULAN}

Berdasarkan hasil kegiatan pengembangan wisata Hutan Mangrove di Desa Waiheru oleh mahasiswa KSM Tematik ialah Desa Waiheru memiliki potensi wisata Hutan Mangrove yang dapat dikembangkan. Melalui prinsip berbasis ekowisata dapat dijembatani hubungan yang baik antara pengelolah dengan masyrakat. Selain itu melalui pengembangan berbasis ekowisata, tidak hanya sebagai pelestarian lingkungan tetapi juga sebagai perjalanan wisata 
dan juga wadah edukasi yang baik serta masyarakat lokal juga turut berkontribusi didalam kegiatan wisata berbasis ekowisata.

\section{DAFTAR RUJUKAN}

Fathani, A. H. (2019). Pemberdayaan Masyarakat Untuk Mewujudkan Desa Mandiri Dan Sejahtera Berbasis Entrepreneur Melalui Pemanfaatan Buah Salak. Jurnal Pembelajaran Pemberdayaan Masyarakat (JP2M), 1(1), 55-58. https://doi.org/10.33474/jp2m.v1i1.5008

Fitriani, P. (2018). Persepsi Masyarakat Terhadap Potensi Obyek Wisata Puncak Ahuawali di Desa Ahuawali Kecamatan Puriala Kabupaten Konawe. Jurnal Penelitian Pendidikan Geografi, 3(4), 84-96. https://doi.org/10.1017/CB09781107415324.004

Hakim, L. (2010). Industri Pariwisata dan Pembangunan Nasional. Among Makarti, 3(5), 70-78. https://jurnal.stieama.ac.id/index.php/ama/article/view/18

Hawing, H., Mutmainnah, \& Nengsi R, R. (2019). Kemitraan Pemerintah Daerah Dengan Badan Promosi Pariwisata Daerah Dalam Pemasaran Objek Wisata Permandian Alam Ompo Kabupaten Soppeng. Jurnal Komunikasi Dan Organisasi (J-KO), 1(1), 1824. https://journal.unismuh.ac.id/index.php/jko/article/view/1771

Natan, N. (2016). Prospek Pariwisata Morotai. Media Wisata, 14(1), 305-316. https://doi.org/10.36276/mws.v14i1.150

Primadany, S. R., Mardiyono, \& Riyanto. (2013). Analisis Strategi Pengembangan Pariwisata Daerah (Studi Pada Dinas Kebudayaan Dan Pariwisata Daerah Kabupaten Nganjuk). Jurnal Administrasi Publik Mahasiswa Universitas Brawijaya, 1(4), 135-143.

Risman, A., Wibhawa, B., \& Fedryasyah, M. (2016). Kontribusi Pariwisata Dalam Peningkatan Kesejahteraan Masyarakat Indonesia. Prosiding Penelitian Dan Pengabdian Kepada Masyarakat, 3(1), 1-154. https://doi.org/10.24198/jppm.v3i1.13622

Rumijati, A., Asfiah, N., \& Fiandari, Y. R. (2021). Peningkatan potensi desa wisata melalui pengembangan kemasan oleh-oleh. Jurnal Inovasi Hasil Pengabdian Masyarakat (JIPEMAS), 4(1), 90-99. https://doi.org/10.33474/jipemas.v4i1.9049

Setiawan, I. (2015). Potensi Destinasi Wisata Di Indonesia Menuju Kemandirian Ekonomi. Prosiding Seminar Nasional Multi Disiplin Ilmu \& Call For Papers UNISBANK (SENDI_U), 978-979. https://www.unisbank.ac.id/ojs/index.php/sendi_u/article/view/3321

Sugianto, A., \& Sholihah, A. (2018). Kelompok Petani Jamur Tiram Putih Di Desa Blayu, Kecamatan Wajak, Kabupaten Malang.Jurnal Inovasi Hasil Pengabdian Masyarakat (JIPEMAS), 1(2), 129-136. https://doi.org/10.33474/jipemas.v1i2.1517

Wolah, F. F. C. (2016). Peranan Promosi Dalam Meningkatkan Kunjungan Wisatawan Di Kabupaten Poso. Jurnal Acta Diurna, 5(2), 1-11. https://ejournal.unsrat.ac.id/index.php/actadiurnakomunikasi/article/view/11722 